\title{
ACE Inhibitor
}

National Cancer Institute

\section{Source}

National Cancer Institute. ACE Inhibitor. NCI Thesaurus. Code C247.

Any substance that inhibits angiotensin-converting enzyme (ACE), an enzyme that catalyzes the conversion of angiotensin I to angiotensin II. Inhibition of ACE results in a reduction in angiotensin II and angiotensin II-induced aldosterone secretion, causing vasodilation and natriuresis. 